\title{
11
}

\section{Five theses for reinstituting economics: Anthropological lessons from Broome}

\section{Stephen Muecke and Ben Dibley}

Sometimes a visit to a country town can give you a feel for larger issues facing the nation. Broome is remote, strongly Indigenous, multicultural and its population swings seasonally from between 15,000 in the steamy wet to 40,000 in the dry, when people migrate north from the southern winter. As we research an ethnography for the Goolarabooloo people, who in 2013 successfully opposed the building of a gas plant on James Price Point, the need to think about competing economic claims arises.

On the one hand, the Western Australian Government, keen to industrialise the Kimberley, worked closely with the Woodside consortium and the Kimberley Land Council to make the gas plant happen, and so further develop a resources sector which on current estimates contributes about $\$ 1.1$ billion annually to the region's economy (Department of Planning 2014). They argued that such industrialisation would bring infrastructure and jobs to the western Kimberley by plugging into 'its largely untapped wealth', which, in terms of offshore resources and energy assets, have a speculative value approaching $\$ 250$ billion (Broome Chamber of Commerce \& Industry 2014). On the other hand, the Goolarabooloo and an alliance of 
environmental groups argued that Indigenous law and culture, along with the environment, was worth protecting, in their own terms, but also as economic resources for an alternative 'cultural and conservation economy' (Australian Conservation Foundation 2011). The tourism industry, worth about $\$ 300$ million to the region annually, kept pretty quiet as the battle raged from 2009-13, even though an oil spill on the famous Cable Beach would close down the industry in Broome, deterring the 210,000 or so tourists who presently visit the town each year (Department of Planning 2014).

These competing stories are of national interest, not least because of the economic boom Australia has experienced with commodity exports, even without a mining tax. But this boom is complicated by other factors: a 'two-speed' economy, the social damage done by flyin/fly-out (FIFO) worker mobility, battles over native title, divisions in Indigenous communities, and environmental damage. Such factors are strong indicators that 'the economy' is not just about economics, which is where environmental humanists like us come in. ${ }^{1}$ We ask questions about human factors as well as non-human ones, on the assumed need to monitor for human well-being, as well as a healthy environment to sustain life.

French philosopher and anthropologist Bruno Latour (2013) has recently written an 'anthropology of the Moderns' (referring to Western Europeans) and he claims that the Economy has become their most cherished institution, wielding a metalanguage of value. It has usurped Nature as it becomes 'second nature' to use this language to make the Economy the 'bottom line'. While he is overstating the case, and the capital E of Economy signals his bold generality, the tendency for economic language to allow 'all peoples to benefit from the same measuring instrument made explicit everywhere in the same idiom' (Latour 2013: 383-4) may well be a significant trend whose unifying, globalising power is the identifiable target of variousequally global - modes of resistance.

He further criticises the Economy's claims to science-driven accuracy or the way it is described as 'the ice-cold, rational, coherent, and continuous manifestation of the calculation of interests alone'

1 In this we share an affinity with the postcapitalist politics exemplified by Gibson-Graham et al. (2013). 
(Latour 2013: 386). But where is this cold hard gaze exactly? Commerce is, in practice, full of heat: surprising new products, marketing tricks, testosterone and stimulant-fuelled traders, fictional goods, cooked books, and outright lies. For the sake of comparison, anthropologists might read Marcel Mauss on the gift and look at 'primitive' economies in the Pacific and 'recoil in panic before the imbroglios that they find described there. "But then," they sigh, "those poor wretches will never get out of it, they'll always be bound, attached, indebted, hooked, enmeshed, entangled"' (Latour 2013: 448-9). Whereas, Latour goes on, in our modern economies 'prolonged hardening exercises have accustomed them to being "quits" with respect to those with whom they enter into transactions ... we've found the way to get ourselves out of such imbroglios by adding to them their exact opposite: "And now we're quits; I owe you nothing; we have exchanged equivalents; goodbye!"' (2013: 449).

What a strange ideal on which to found an economy! You turn someone close into a stranger; you want to close deals as if getting away from one another were the aim. But in fact nobody lives according to the principles of this idealised Economy, where equivalent values are precisely and coldly calculated. Our actual economic behaviour is just as mixed up and intimate as any Pacific bartering system. In economics as in everything, it turns out, we are attached to each other and to what we value. In Broome you might call it a lifestyle, on the trading floor in the city it might be a stock correction.

This somewhat loose characterisation of the Economy (with a capital E) is undertaken nonetheless with an anthropological attitude, where the anthropologist takes with a grain of salt the extravagant claims his informants are making about this 'system': its ubiquity, its providence for all, its objectivity, and its freedom. It is in this anthropological spirit that we turn to Broome where this same economy was invoked as embodying all the good reasons for putting a heavy LNG (liquefied natural gas) industrial precinct on Goolarabooloo ancestral land. Here we could be forgiven (with some hindsight given the project is now abandoned) for invoking the figure of Darryl Kerrigan from the film The Castle shouting 'Tell 'em they're dreaming!' as we search for a technical term to describe an economic model that is so out of touch with the local country's needs that it is ... what? ... fantastical? 
The $\$ 45$ billion gas plant was to be built by the Joint Venture Partners led by Woodside without any economic modelling, as described by Matt Grudnoff (2012):

The state government decided not to undertake an economic modelling process because it argued that 'no model was determined sufficiently appropriate to accurately quantify the economic impacts of the Precinct.'

Having stated that no economic modelling was done, the government's report then says it:

'seeks to broadly examine and qualitatively analyse the macroeconomic impacts of the expenditure and investment associated with the LNG Precinct, including the impacts on GDP, income, prices and fiscal variables'.

Achieving this goal is extremely difficult without a robust economic modelling exercise.

Without going into all the details, Grudnoff's analysis demonstrates that the good reason for not doing the modelling would have been to hide the fact that the only significant beneficiaries would be the major shareholders of the companies involved.

The project was shelved after four years of massive expenditure of resources and energy, on the part of activists on both sides. Those seeking to protect Indigenous sites in the Kimberley see the next big threat coming from companies like Buru Energy seeking to frack the Canning Basin, but that too now looks highly doubtful. What is going on with these massive plans for industrialisation that the Government of Western Australia tries to push through without any viable planning? Naturally, they meet with resistance, which our ethnography will describe, but we also want to go another step, which anti-capitalist discourses generally do not take. We want to take the risk of sounding naïve by suggesting that the Economy, as deployed in these instances, needs to be reinstituted, reformed, or completely reset in the light of the actual interests of the significant (and indeed 'insignificant') stakeholders.

To this end we'd like to offer five theses - though perhaps it ought to be 11 ! - for resetting or reinstituting the Economy. 


\section{Thesis No. 1: Economies should recognise that their variables are contingent rather than necessary}

Broome makes visible the possibility that there are whole communities of people relatively indifferent to the Economy, because they have another more 'traditional' economy to which to turn. Such communities might be somewhat immune to a narrative that tries to carry the imperative that 'it is only a matter of time' before Broome is 'developed'. If it is finally recognised that the Western template of economic modernity is but one among many, that even non-Western peoples can sustain different modernities, then it should be agnostic, finally, and begin more serious negotiations about its limits, what values it touches, and its limited mission in a place. Economic contingencies, then, are the 'sticky' localised factors to which economic endeavours inevitably find themselves attached. They are the additional expenses, the delays, the demands for a 'social licence', the roundabout negotiations and even corrupt deals, none of which are part of the template of a universalising modernist economics, but which are put down to 'skill', 'experience' or even 'business in confidence' secrets. Making these contingencies explicit in regards to local demands would have the effect of renaturalising in each new case, or meaningfully adapting to local circumstances.

\section{Thesis No. 2: The Economy should be deflated so that it is not the only game in town, so that it does not (aspire to) determine all values, so that incommensurate values can continue to be sustained in parallel by religion, the law, politics, science and education}

The redemptive promise of the economic script endlessly heralded in government reports and corporate prospectuses is one in which the horizon of universal prosperity is to be reached without friction. Through cool heads and hard work economic salvation awaits all. 
Yet the calculative script belies the volatility of the people and the things that it sets in motion and whose passions and energies generate much friction and heat. The promise of prosperity to be piped from the beneath the ocean's floor and distributed from the James Price Point LNG precinct proved not to be the conduits through which commerce would indifferently flow, a flow to which nothing would stick, but rather the trenches from which a cosmopolitical war came to be waged. The sages of the Economy found themselves confronted by others with cosmologies in which the presence of 'the invisible hand' was nowhere to be found, and in which the 'second nature' of the Economy was anything but common sense. As other worlds, other logics, other values pressed in on those of the Economy, Premier Colin Barnett's ambition for an industrialised Broome was - for now at least-reduced to a pipe dream.

Yet, even in defeat, the sphere of the Economy remained inflated. True to the calculative script and apparently unmoved by its cosmopolitical skirmishes, Woodside coolly withdrew from the James Price Point project. With the risks outweighing the opportunities for shareholders, the project was considered no longer economically viable. Calling it quits - the company left town. Where did that leave the microcosmic 'Broome economy'? Some blamed a few retail closures on this pull-out, hopeful that there was evidence that heavy industry was always going to be the town's saviour. Others, like the Goolarabooloo, remained exhausted but unmoved since their relation to the mainstream economy was one that always saw it 'deflated', not as their main concern, not their main business. Their expression of sovereign indifference was a brave mask over the danger that this economic intrusion would have the capacity to reinforce their precarious economic marginality. Our third thesis, riffing on Jon Altman's hybrid economy, disrupts such a narrative that would have the mainstream inevitably swallowing up margins.

\section{Thesis No. 3: Economies are-especially in Aboriginal Australia-hybrid}

If the successful campaign which saw Woodside's retreat from James Price Point challenged the ruling elite's conviction that the Kimberley's industrialisation was inexorable, it also troubled Premier Barnett's 
assertion (there was no economic modelling after all) of a direct correlation between this development and Indigenous economic gain. Without gas development in the Kimberley, an embattled Barnett retorted, 'there will be no gas-related economic development in the Kimberley and there will be no economic benefit for the Aboriginal people of the Kimberley' (cited in Australian Conservation Foundation 2011). Repeating the received wisdom of dominant policy discourse in Australia, which assumes that Indigenous poverty can only be alleviated with modernisation and its development programs, the rationale behind Barnett's veiled threat was as familiar as it was unconvincing. Certainly the Goolarabooloo were unpersuaded. A gas plant was equivocally not an entity to which they saw their well-being as attached, financial or otherwise.

Altman's hybrid economy offers a way out of this impasse on Indigenous economic well-being. Taking an ethnographic turn within the discipline of economics, Altman's work contributes, we contend, to a certain deflation of the Economy, expelling the (hot) air of those who would elevate it as the only redress to Indigenous disadvantage. Altman's conceptual-cum-political innovation is in expanding and diversifying what counts as economic activity in remote Australia and considering how such activity cuts across the sectors of the market, the state and the customary (for a pertinent example see Altman 2009). Altman advances the hybrid economy as a critical analysis and alternative model of economic development to those rolled out by a neoliberal administration. His is a powerful heuristic for emphasising Indigenous engagement in a diversity of economic activities and livelihood sources which evidence creative postcolonial adaptation (e.g. Altman 2010). We continue and widen Altman's emphasis on Indigenous agency, and the issues of 'difference but relatedness' that he stresses, by insisting that the economies of remote Australia are not only institutionally hybrid, they are also ontological hybrids. This is in recognition that economic agents are organised, disorganised and reorganised not only in relation to different forms of institutional practice, but also in the relations between human and non-human actors. This is the contention of our fourth thesis. 


\section{Thesis No. 4: Economies are 'more than human' and as such they should recognise their non-human stakeholders}

The Woodside fiasco makes clear that there are many more actors than those included in the calculative script of the Economy. From geological forces and cosmological entities to cyclones and bilbies, each performed a political agency in whose presence, as it turned out, economic decisions needed to be made. Such recalcitrant non-humans could not be ignored or abandoned as 'externalities' beyond the sphere of the idealised Economy. They were not grit in an otherwise frictionless flow. Rather, they demonstrated that the agency of an economic assemblage is always distributed across an overflow of human and non-human entities. Economies, we contend then, must be considered as 'confederations' in which the non-humans have a stake and a political claim for representation; that is, if the economic is to be brought down to earth (Bennett 2010).

\section{Thesis No. 5: Economies must be earthbound}

Economic activity based on country where people live has to recognise that it is earthbound; henceforth it will not be a case of 'closing deals' to 'get away' with extracted value. So for this to happen a few other concepts need to be reinstituted or reset, notably Nature. Now that the Anthropocene has moved front stage, Nature as the stable backdrop to human activity is an idea as dangerous to human existence as the notion of the Economy as second nature. Earthbound economies cannot be as the Economy was for the Moderns - one of detachment and freedom seemingly unconstrained by material limits, as if we have multiple planet Earths at our disposal. Rather, facing a 'ticklish' Gaia - an Earth whose systems respond to our actions - such economies must become ones of attachment, of responsibility. Earthbound economies, then, must be immunological by design, integral to the sociotechnical and organic envelope that sustains 'a breathable atmosphere' for humans, for their existence (see Sloterdijk 2013). 
Was it really a kind of certainty derived from huge wealth that hardened the hearts of the oligarchs, leading them to think that 'we owe nobody anything'? The trouble is, the biggest creditor of all is coming back to bite them: the Earth. And it is telling them 'you owe me everything, your immense personal wealth does not make you unassailable. Your wealth is in "bonds drawn against the treasure of the Earth"' (Latour 2013: 449); dollars and euros mean nothing now, they give you a false freedom from debt. Your Earth bonds have always tied you to the values that really mattered to you: the good life. What you value most is actually in danger: a high-quality meal as opposed to an unhealthy one; really enjoyable associations with other beings as opposed to fake ones.

Could such a simple lesson really be learned from visiting a remote country town where rival economies are playing out their dramas? We hope to have shown that the evidence is there that assemblages of human and non-human values (what the Environmental Humanities takes seriously as a field) are so strongly held by local stakeholders that they have been able to deflect the might of a powerful consortium of multinational companies with the forceful backing of the state and sympathetic media campaigns. These were values that the universalising narrative of the Economy did not engage; this is why we have argued that economies need to be more realistic about what they do. They cannot arrive in new places with an old European idea of what Nature is and couple it to an overconfident machinery of the Economy as the predominant 'second nature' of human society. If organisations are not prepared to reinstitute economies under local conditions, negotiations will break down as they did every step of the way for Woodside's adventure in Broome.

\section{References}

Altman JC (2009). Indigenous communities, miners and the state. In Altman JC \& Martin DF (eds), Power, culture, economy: Indigenous Australians and mining, CAEPR Research Monograph No. 30, ANU E Press, Canberra. 
Altman JC (2010). What future for remote Indigenous Australia? Economic hybridity and the neoliberal turn. In Altman JC \& Hinkson M (eds), Culture crisis: anthropology and politics in Aboriginal Australia, UNSW Press, Sydney.

Australian Conservation Foundation (2011). Briefing paper: economic futures for northern Australia, Australian Conservation Foundation, Carlton VIC.

Bennett, J (2010). Vibrant matter: a political ecology of things, Duke University Press, Durham, NC \& London.

Broome Chamber Of Commerce \& Industry (2014). Submission No. 125 to the Inquiry into the development of northern Australia, House of Representatives Joint Select Committee on Northern Australia, Parliament of Australia, Canberra, 28 March.

Department of Planning (2014). Kimberley planning and infrastructure framework, Department of Planning, Government of Western Australia, Perth.

Gibson-Graham JK, Cameron J \& Healy S (2013). Take back the economy: an ethical guide for transforming our communities, University of Minnesota Press, Minneapolis.

Grudnoff M (2012). James Price Point: an economic analysis of the Browse LNG project, Policy Brief No. 40, The Australia Institute, Canberra.

Latour B (2013). An inquiry into modes of existence: an anthropology of the moderns, translated by Catherine Porter, Harvard University Press, Cambridge MA.

Sloterdijk P (2013). In the world interior of capital: towards a philosophical theory of globalization, Polity, Cambridge UK. 
This text is taken from Engaging Indigenous Economy: Debating diverse approaches, edited by Will Sanders, published 2016 by ANU Press, The Australian National University, Canberra, Australia. 